\title{
A dimensão ético-moral no discurso da corrupção: um gesto de leitura
}

Anderson FERREIRA

\section{Considerações iniciais}

O propósito deste capítulo é examinar a dimensão ético-moral no discurso da corrupção. Para isto, construímos a formação discursiva temática "corrupção", a partir de práticas discursivas acerca do fenômeno da corrupção no Brasil. Fundamentamo-nos no aparato teórico-metodológico fornecido pela Análise do Discurso em sua perspectiva enunciativo-discursiva, mobilizando a categoria de cenografia, postulada por Maingueneau (1997, 2006, 2008, 2011, 2013, 2015, 2016). Na próxima seção, apresentamos as condições de enunciabilidade do corpus de análise e a maneira pela qual a palavra corrupção atravessa esse corpus. Na seção seguinte, procedemos a um arranjo entre a noção de cenografia 
verbal e digital e os discursos publicitário e jornalístico em foco. A análise, propriamente dita, consta da última seção, que é seguida das considerações finais.

\section{A corrupção é o outro}

A General Motors (doravante, GM) lançou, em 2017, uma campanha publicitária para apresentar ao consumidor brasileiro seu novo carro, ressaltando a ideia de mudança e movimento signos de pertencimento da contemporaneidade. Vinculado em diversas mídias, o filme apresenta, de acordo com o site oficial do Clube da Criação, "imagens de manifestações de rua e de pessoas indignadas nas redes sociais, por conta de comportamentos antiéticos". Também convida o público a "refletir e buscar uma mudança de atitude, mostrando que a transformação do mundo começa dentro de cada um e em cada gesto".

A conjuntura política brasileira nos últimos anos dá sustentação à campanha da montadora norte-americana. A enunciação publicitária da GM recupera os propósitos democráticos em face do engajamento cívico e político dos cidadãos brasileiros contra a corrupção no meio político. Nesse sentido, o discurso publicitário da GM relaciona o "novo" carro ao direito de "exigir mudanças". E, por meio de instrumentos democráticos legítimos, associa o direito da reivindicação cívica à derrocada da corrupção.

Acontece que o discurso publicitário da GM foi atravessado por um gesto de leitura de um leitor "indesejado", que não se marca pelo anonimato. Trata-se de um leitor que fala do lugar do jornalismo e desse lugar ele é capaz de ocupar outro lugar: o de produtor de conteúdos jornalísticos. Esse espaço clivado ocupado por leitor- 
-produtor é possível por causa da internet que fornece a possibilidade de coprodução dos efeitos de sentido num tempo quase nulo (GIDDENS, 1991). Nesse espaço, recuperamos esse atravessamento construindo uma Configuração por meio da formação discursiva temática "corrupção".

Na contemporaneidade, a restrição semântica da palavra "corrupção" deve-se a uma percepção histórica do fenômeno. Essa percepção procura não apenas examinar as causas do problema, mas criar mecanismos para sua minimização. De fato, a palavra corrupção circula com certa mobilidade pelos mais variados setores de atividade social. Ela pode mediar conversas nas praças públicas, nos centros comunitários, na feira livre, no Senado etc. Abundante na mídia, ela redesenha cenários do mundo do tráfico e da política ao mundo da moda e do esporte. Como bem lembrou Orlandi (1995, p. 111), "quando uma palavra significa é porque ela tem textualidade, ou seja, porque a sua interpretação deriva de um discurso que a sustenta, que a provê de realidade significativa”. Mas, embora moeda corrente, ela é recebida, de maneira geral, pelo seu aspecto danoso.

Nas sociedades ocidentalizadas, há certo consenso de que a corrupção é um mal a ser controlado e combatido, pois se trata de um fator de desagregação do sistema social, político e judiciário. Esse consenso, de modo geral, é produzido quando a corrupção institucional se torna pública. Nesse ponto, a crítica visa à perspectiva funcionalista do problema, destacando suas disfunções e seus efeitos negativos sobre a sociedade. Assim, tomada em termos de ilegalidade, condena-se o ato corruptor no nível das instituições. Mas, quando esses atos ali se aprofundam, o debate no campo social se dirige ao nível individual e, de modo específico, a corrupção é tomada em termos de ética e moralidade. 
A frase "Seja a mudança que você quer ver no mundo", atribuída a Mahatma Gandhi, evidencia esse processo. Nela fica implícita que a mudança do mundo social passa pela mudança individual. Isto é, para que a corrupção institucional seja combatida, seria necessário combater a corrupção dos pequenos atos [corruptos] individuais. Sem nos opor a essa premissa, é possível aventar que, tanto no nível institucional como no individual, a corrupção pode ser benigna.

No nível institucional, em que pese um sistema jurídico arcaico e moroso, a corrupção pode contribuir para aperfeiçoar o funcionamento desse sistema. No nível individual, ela pode ser usada por grupos historicamente marginalizados. Este último nível implica tensões entre classes sociais e, em particular, está ligado à questão das desigualdades sociais e econômicas, conforme apontam Bobbio et al. (2009. p. 293),

Nas sociedades fragmentadas e heterogêneas, em que existem discriminações em relação a determinados grupos, é provável que os grupos discriminados tendam a agir de forma solapada, para não tornar mais aguda a discriminação de que fizeram objeto, mediante uma clara atividade de pressão. O fenômeno da Corrupção acentua-se, portanto, com a existência de um sistema representativo imperfeito e com o acesso discriminatório ao poder de decisão. A última variável assenta no grau de segurança de que goza a elite que está no poder. Quanto mais esta se sentir segura de conservar ou reconquistar o poder por meio legais ou recear ser punida usando meios ilegais, tanto menor será a Corrupção. Quanto mais ameaçada se sentir, tanto mais a elite recorrerá a meios ilegais e a Corrupção para se manter. 
De outra forma, em ambos os níveis, as práticas discursivas em torno da unidade temática "corrupção" iluminam os aspectos morais - que estariam intrínsecos numa dada cultura - e apagam suas relações históricas, em termos de luta de classes e de desigualdade social e econômica. Instituem, assim, a crença na cultura da malandragem, ao mesmo tempo em que constroem um templo norte-americano e europeu da moral, ligando parte dos países em desenvolvimento à incivilidade. A corrupção, no que tange à dimensão ético-moral, é o outro.

O modo pelo qual retomamos a temática da corrupção na Configuração [1] permite apreendê-lo no campo das tensões entre classes sociais que se direcionam pelo caráter ilícito no tocante ao exercício de influência. Nessa perspectiva, em sociedades fragmentadas e heterogêneas como a brasileira - onde existem discriminações em relação a determinados grupos e cisões sociais e econômicas profundas - o conceito de corrupção é objeto de luta.

\section{As cenografias em arranjo}

Em virtude de nossa filiação teórico-metodológica neste trabalho, vamos abordar a dimensão ético-moral no discurso da corrupção pelos dizeres e pelos lugares que os autorizam. Esta tomada de posição tem por objetivo enfocar a preeminência e a preexistência da topografia social e da cronografia temporal sobre o sujeito que nelas se inscreve. Espaço, tempo e sujeito são, portanto, elementos constitutivos da enunciação.

Mas a instância enunciativa se constitui de modo paradoxal. Ela eleva o indivíduo à condição de sujeito ao passo que o determina sócio-histórico e culturalmente, submetendo-o a suas regras 
e, ao mesmo tempo, legitimando-o no bojo dessas mesmas regras (MAINGUENEAU, 1997). À medida que a enunciação associa sujeito, espaço e tempo, põe em evidência regimes de fala capazes de mobilizar, para compor as cenografias, cenas de fala validadas por um grupo em dada cultura (MAINGUENEAU, 2006, 2008, 2011, 2013).

Para o tipo de Configuração que construímos, recorrendo ao espaço da Web, falaremos, então, de cenografias num quadro verbo-imagético. Para Maingueneau (2015, p. 162), a cenografia, neste quadro, precisa ser apreendida pelo seu estatuto digital, pois ela se configura ao mesmo tempo como "uma imagem na tela, um suporte de operações [...] um constituinte da arquitetura do site no qual ela figura". Conforme este autor, a cenografia digital pode ser analisada em três componentes:

[1] Um componente iconotextual (o site mostra imagens e ele mesmo constitui um conjunto de imagens na tela);

[2] Um componente arquitetural (o site é uma rede de páginas acionada de uma determinada maneira);

[3] Um componente procedural (cada site é uma rede de instruções destinadas ao internauta).

A cenografia digital resulta da interação entre estes três componentes, que podem convergir ou divergir (MAINGUENEAU, 2015, p. 163). 
Em nosso caso, a cenografia digital construída em cada discurso selecionado para análise se apoia em cenas de fala dispersas, mas que, tomadas num conjunto, evocam a dimensão ético-moral no discurso da corrupção. Pelo menos provocam uma pequena “implosão" no interior dessa dimensão.

Ao construirmos a Configuração [1], colocamos em relação duas cenografias:

- Uma cenografia de protesto anticorrupção constitutiva das condições sócio-políticas brasileiras de 2013 em diante.

- Uma cenografia jornalístico-investigativa, que, reagindo à primeira, reúne elementos (imagens, dados estatísticos, fontes) para enunciar tal qual uma investigação jornalística, na tentativa de iluminar a dimensão ético-moral da corrupção (você não tem moral para falar disso!).

Por isso, a cenografia digital construída no discurso jornalístico converge para o componente iconotextual: "o site mostra e ele mesmo constitui um conjunto de imagens na tela" (MAINGUENEAU, 2015, p. 162). Essa estratégia visa a deslegitimar a cenografia digital (e não apenas a cenografia verbal) construída no discurso publicitário.

Ambos os discursos constroem cenografias apoiadas em cenas de fala instauradas na memória coletiva, as quais são validadas enquanto expressão institucional e "esquecidas" enquanto expressão individual, mas que podem ser encontradas como estereótipos na cultura, no que diz respeito, em particular, às questões ético-morais da sociedade brasileira. Mas aqui é preciso fazer outra distinção acerca do corpus construído para Configuração [1].

O gênero de discurso “anúncio publicitário" é a realização em- 
pírica do discurso publicitário. Mas esse discurso utiliza o caráter mimotópico ${ }^{6}$ para se realizar. De fato, o discurso publicitário tem como característica a utilização de diferentes gêneros de discurso para apresentar sua fala. Ele "mobiliza o discurso sincrético, isto é, constitui-se pela produção de diferentes linguagens com a combinação de imagens, música, palavras" (NASCIMENTO e FERREIRA, 2016. p. 260). No discurso publicitário de nosso corpus, a cenografia digital é bem-sucedida porque reúne de modo exemplar os componentes iconotextual, arquitetural e procedural.

O discurso jornalístico em análise, por sua vez, tem a sua enunciabilidade ligada ao discurso publicitário, contudo procura subvertê-lo naquilo que diz respeito à sua cenografia e ao conteúdo temático proposto por ela. Num processo de coprodução, o co-enunciador-leitor do discurso publicitário não recebe o filme produzido pela agência publicitária como uma publicidade de carro da GM, mas por uma cenografia de protesto anticorrupção, materializada no gênero de discurso de estatuto mimotópico: "manifestação de rua”.

Contudo, o enunciador do discurso jornalístico evoca um leitor-modelo que subverte a cenografia construída na publicidade. Trata-se de um leitor investigativo, atento, crítico; com a capacidade da não-aderência à cenografia construída pelo discurso publicitário. Desse modo, o enunciador-leitor do discurso jornalístico toma o discurso publicitário por sua finalidade secundária: protestar contra a corrupção e não por sua finalidade primeira: vender um produto. ${ }^{7}$ Enquanto o discurso publicitário imita o gênero de discurso "manifestação de rua", pondo em pauta a questão da cor-

6 Mimotópico seria uma representação do lugar, ou seja, uma mímica que resultaria na imitação do lugar onde se localiza o discurso tópico, ou melhor, uma imitação do discurso tópico, uma capacidade que o discurso publicitário teria de se camuflar em outras formas de discurso (Cf. MAINGUENEAU, 2010).

7 Nesse sentido, a não-aderência, de certo modo, falha. 
rupção, o discurso jornalístico, como veremos, ilumina a dimensão ético-moral desse estratagema mimotópico.

Na cenografia digital, construída no discurso jornalístico, o site jornalístico em questão constitui um conjunto de imagens de forma a recuperar para o seu leitor as contradições entre aquilo que diz o discurso publicitário e aquilo que a instância jurídica implicada nele faz. Nessa senda, o enunciador do discurso jornalístico enuncia por uma cenografia jornalística investigativa, mas recorrendo, na mesma dimensão ético-moral de seu antagonista, a cenas de fala valorizadas na cultura brasileira recente, isto é, as cenas do campo da ética e da moral.

Vejamos, então, a Configuração [1].

Configuração [1].

Discurso publicitário [1]. ${ }^{8}$

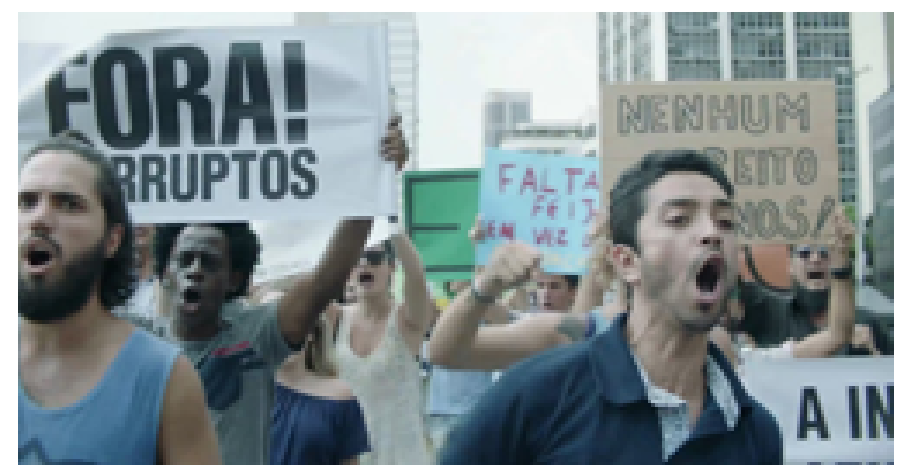

Figura 1. Encenação de atos contra corrupção

8 Disponível em: <http://www.clubedecriacao.com.br/ultimas/sejaamudanca/>. Postado em: 27 fev. 2017. Acesso em: 17 ago. 2019. 
[\$1] "Somos um povo que aprendeu a exigir mudanças e que tá mudando pra servir de exemplo, que não aceita menos do que o justo, que cansou da malandragem e que acelera na direção certa. Somos um povo que entendeu que sua força vem de cada pessoa, porque, na prática, a mudança começa com você. Novo Chevrolet Cruze você na direção da mudança”.

Fonte: Clube de Criação

Discurso jornalístico [2]. ${ }^{9}$

\section{Hipocrisia sobre rodas: GM vende carro "contra corrupção" mas é condenada por fraudes}
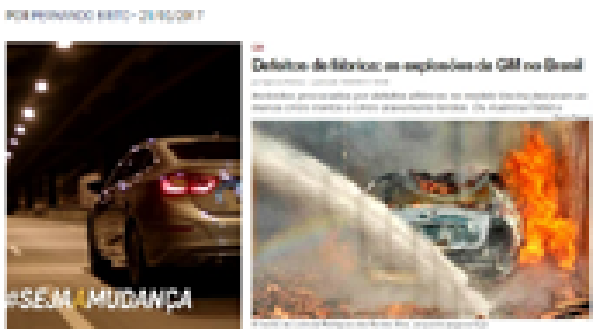

Figura 2. Fotomontagem. GM do Brasil

[\$1] A General Motors está lançando uma campanha milionária para vender seu modelo Cruze em que, com passeatas e jornais "fake" diz para as pessoas terem uma "mudança de atitude" e que "não aceitamos menos que o justo e que cansamos da malandragem e do jeitinho".

9 Disponível em: <http://www.tijolaco.com.br/blog/hipocrisia-sobre-rodas-gm-vende-carro-contra-corrupcao-que-e-acusado-de-fraude/ > Postado em: 21 fev. 2017. Acesso em: 17 ago. 2019. 
[\$2] Ok, muito bem, embora misturar civismo e automóvel seja uma coisa pra lá de capciosa, coisa que a Fiat já fez com o tal "vem pra rua" com resultados duvidosíssimos.

[\$3] Ocorre que a GM joga pedras, mas tem telhado de vidro.

[\$4] Com o mesmo modelo Cruze que ela quer vender com o discurso "politicamente correto", a empresa está sendo acusada de fraudar as medições antipoluição nos Estados Unidos.

[\$5] Com outros modelos, por conta de defeitos de fabricação, demora no recall e perda de valor dos veículos, a GM sofre processos bilionários.

[\$6] E aqui mesmo no Brasil, arrasta-se há anos o caso judicial envolvendo a montadora com incêndios, num total de 32 acidentes e 24 vítimas fatais. A Agência Pública, na Carta Capital, publicou matérias com o relato dramático das mortes, inclusive a de uma menina de sete meses, envolvida pelas chamas no carro da mãe, na garagem de casa.

[\$7] Que tal a GM, que consumiu dinheiro público para não falir na crise de 2008, começar a seguir os conselhos que ela própria dá, no comercial, quando sugere às pessoas a refletirem e buscarem uma mudança de atitude. Fonte: Tijolaço

No discurso publicitário [1] o texto abaixo da imagem é objeto de locução durante o filme. No site, a cenografia digital construída reúne de modo bastante exemplar os procedimentos iconotextual, arquitetural, procedural. Mas o leitor da publicidade interage com um vídeo e a locução do texto, pois a materialidade em questão, 
também, fora exibida em outros mídiuns. ${ }^{10}$ No vídeo, é possível observar, no espaço da cidade, pessoas jovens erguendo cartazes, em que se pode ler: "Nenhum respeito a menos", "Fora corruptos", "Ética"; tais quais os usados em protestos anticorrupção recentes pelo Brasil. Ao final do texto narrado, lemos o slogan: "Novo Chevrolet Cruze você na direção da mudança”.

Como adiantamos acima, o discurso publicitário [1] é apresentado por uma cenografia de protesto anticorrupção. A cenografia se apoia em cenas de fala validadas na conjuntura político-midiática do Brasil nos últimos anos, mas procura recuperar modelos valorizados: a manifestação cívica contra a corrupção, o engajamento político, a participação cidadã; cenas valorizadas na cultura brasileira recente. Mas esses modelos valorizados sofreram, na construção da cenografia do discurso publicitário [1], uma espécie de higienização.

O figurino, o cenário e o espaço da cidade, no que diz respeito às cores, contrastam com as matizes vistas nas manifestações reais no Brasil, em particular, em 2016. Nos grandes centros, como a cidade de São Paulo, os protestos ocorriam, em geral, em dias diferentes, mas com a montagem abaixo podemos observar, num só quadro, as cores mais predominantes naqueles protestos.

10 A respeito dos mídiuns ver, neste livro, o trabalho de Nardocci e Nardocci. 


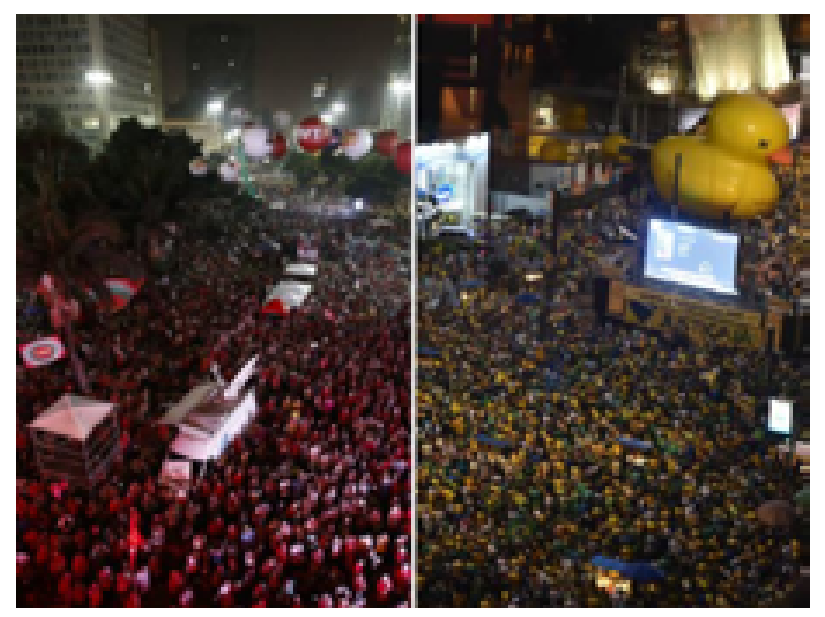

Figura 3. Vermelho e verde e amarelo

No discurso publicitário [1], os cartazes, também, não trazem as cores vermelha e branca e verde e amarelo, tampouco fazem referências às instituições, como era possível observar nas manifestações de rua reais. Os atores e atrizes do filme são jovens e, em sua maioria, homens e brancos. Suas expressões faciais mimetizam revolta e engajamento.

A cenografia de protesto anticorrupção engaja o leitor na luta contra a corrupção no nível institucional, mas ele é convidado a mudar a partir de si: "\#SEJAAMUDANÇA", ou seja, a luta contra a corrupção precisa ter início no nível ético, a partir de cada um de nós, como filosofou Gandhi. Esse movimento discursivo cria um efeito de sentido inesperado: nega uma orientação ideológica na participação política do país, ao mesmo tempo em que ideologiza essa participação de pressupostos políticos neutralizados.

Uma das razões que explicam a apresentação da publicidade por meio de uma cenografia de protesto anticorrupção "neutra", 
pode ser encontrada nas condições de produção político-partidária no Brasil, a partir de 2014, especialmente. Na ocasião, a mídia iluminou os enunciados que materializavam uma polarização entre pessoas que apoiavam o governo de situação, democraticamente eleito em 2014, e as pessoas que apoiavam a oposição que saíra derrotada daquelas eleições.

Nesse quadro, o discurso publicitário investe numa terceira via possível. Para isso, é preciso apagar as cores (e designações) mais presentes nas manifestações de rua reais que, na época, (também as cores!) se tornaram signo de pertencimento. Assim, o enunciador do discurso publicitário [1] projeta seu dizer na fronteira entre os polos político-partidários, predominantes no cenário brasileiro da época, como podemos observar no esquema abaixo:

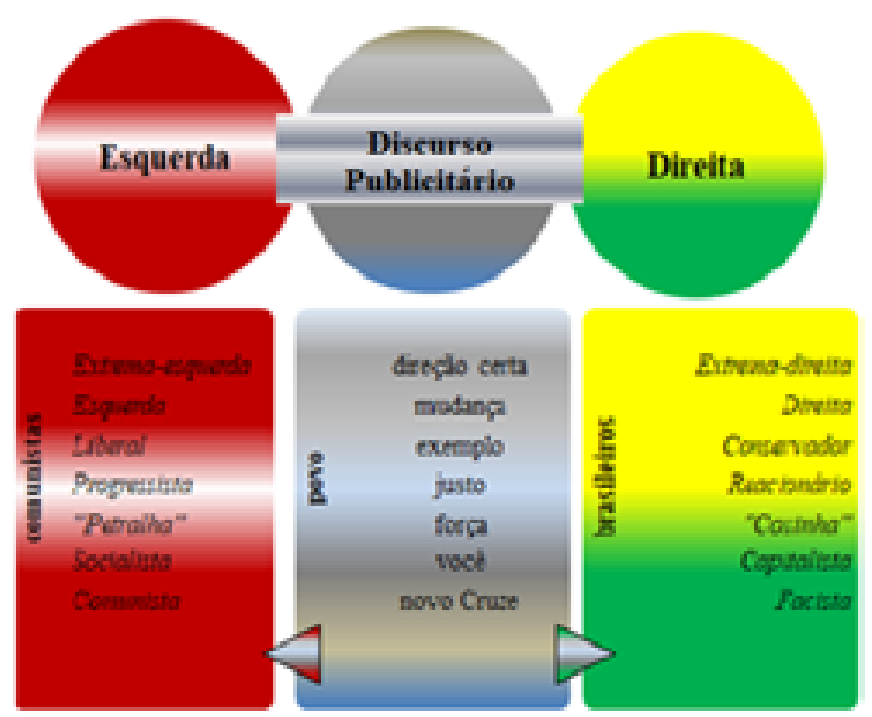

Esquema 1. Vermelho, neutro e verde e amarelo 
É compreensível que um discurso publicitário, que tem como finalidade primeira vender um produto, se "neutralize" no tocante a posições político-partidárias, afinal, ele visa ao consumidor e não ao eleitor. De certo, à época do lançamento da campanha da GM, o discurso da polarização político-partidária convocou militantes, dividiu amigos e familiares, incitou o ódio, obliterou e pulverizou o debate, ocupando espaços êmicos, fágicos, não-lugares e lugares vazios (BAUMAN, 2001). Além disso, o discurso da polarização realocou os indivíduos à esquerda ou à direita do espectro político-partidário, o que criou dicotomias, bifurcações e a superficialização nos debates públicos. Nesse sentido, a "mudança" não poderia estar, em tese, em nenhum dos dois polos.

Nesse cenário, o discurso publicitário [1] vinculado à GM pretende persuadir o leitor-consumidor, instituindo uma cena de enunciação que legitima a cenografia construída. Trata-se de se comunicar não apenas com um consumidor em potencial, mas com aquele que "aprendeu a exigir mudanças e que tá mudando pra servir de exemplo [...]". Para tal, é preciso constituir um regime de fala "externo" aos polos já instaurados na política partidária brasileira à época da companha publicitária, e, então, com base nele, "propor alternativas".

Assim, emerge da cenografia do discurso publicitário [1] um ethos de um indivíduo que, embora "aprendeu a exigir mudanças [...]" "não aceita menos do que o justo [...], cansou da malandragem e [...] acelera na direção certa". Nesse procedimento, é possível notar que a temática da "corrupção" é tomada tanto no nível institucional, "Somos um povo que aprendeu a exigir mudanças"; quanto no nível individual, "Somos um povo que entendeu que sua força vem de cada pessoa".

Com isso, o regime de fala no discurso publicitário [1] salien- 
ta que "a transformação do mundo começa dentro de cada um e em cada gesto" e, mesmo que a corrupção não deixe de ser uma realidade institucional e cultural, [somos um povo que] "cansou da malandragem". Os "comportamentos antiéticos", desse modo, se referem mais ao ato corruptor do que à corrupção propriamente dita. De um lado, o enunciador do discurso publicitário [1] apreende a corrupção naquilo que ela tem de institucional, portanto, visa a associá-la às condições sócio-políticas da época da campanha publicitária e, de outro, naquilo que ela tem de individual, portanto, visa a associá-la ao exercício individual do consumo: "você na direção da mudança”.

Mas o enunciador do discurso publicitário [1] apaga a relação de consumo existente entre empresa e consumidor e evoca a voz do "povo": corpo jurídico, elemento humano do Estado. A relação, agora estabelecida, se configura pelos embreantes de pessoa $<$ nós $>$ e $<$ você $>$. [Nós] "somos um povo"; "a mudança começa com você". O aspecto de "ato individual" (atitude ética) em direção à mudança é ativado pelo embreante $<$ você $>$. Ou seja, $<$ você $>$ é aquele que, no momento da enunciação, interage com a cenografia verbal e digital (MAINGUENEAU, 2015; 2016). Logo, o co-enunciador-leitor, no momento da produção da leitura, é solicitado a participar da mudança.

O co-enunciador-leitor, também, é apreendido pelos tempos verbais. Ele deve colocar-se como aquele que "<aprendeu $>$ a exigir"; "<tá mudando> pra servir de exemplo"; "< $<$ não aceita $>$ menos que o justo"; "<cansou> da malandragem"; "<acelera $>$ na direção certa" e "<entendeu> que sua força vem de cada pessoa". Nessa perspectiva, o tempo verbal no passado recupera aquilo que, supostamente, partilha um pensamento retrógrado: o comodismo, o jeitinho brasileiro, a benevolência, a malandragem; cenas de fala rejeitadas na cultura brasileira contemporânea. A forma nominal 
do verbo no gerúndio indica a "evolução" do pensamento, o movimento da mudança, <tá mudando $>$, ao passo que o tempo presente indica a plena realização da mudança, em suma, o novo: $<$ cansou $>$; $<$ acelera $>$; <entendeu>.

Trata-se de uma transição entre o passado cultural de uma sociedade estagnada democraticamente e o presente plenamente democrático. Presente contido na ideia de participação cidadã e liberdade de direitos individuais. Nesse conjunto, a instituição GM se inclui no grupo instaurado pelo <nós $>$, isto é, no grupo do povo. Logo, a relação direta entre produto e consumidor se apaga, dando lugar a unidade social, o combate contra a corrupção com base na mudança produzida a partir de/por nós mesmos.

O enunciador do discurso publicitário [1] evoca, numa cenografia de protesto anticorrupção, um leitor-modelo que possui uma competência sociocultural capaz de apreender o discurso do comodismo, da malandragem e do jeitinho brasileiro como modelos a serem rejeitados. "Somos um povo que aprendeu a exigir mudanças [...]"; "Somos um povo [...] que cansou da malandragem". Assim, o co-enunciador é convidado a promover uma intervenção no espaço social, entendido como espaço de liberdade, para poder transformá-lo a ponto de "dirigir" a mudança, partindo do seu próprio lugar, entendido como mais seguro. Um movimento explícito da conduta ética no campo da moral.

Convocamos, agora, para o debate o enunciador do discurso jornalístico [2]. Trata-se, como já comentamos, de um enunciador-leitor-modelo. Em seu gesto de leitura do discurso publicitário [1], ele separa do seguimento <nós-povo $>$ o enunciador da publicidade e o toma como sujeito responsável pelo dito, isto é, o toma pela instância jurídica GM: 
[\$1] A General Motors está lançando uma campanha milionária para vender seu modelo Cruze em que, com passeatas e jornais "fake" diz para as pessoas terem uma "mudança de atitude" e que "não aceitamos menos que o justo e que cansamos da malandragem e do jeitinho".

Esse gesto de leitura produzido pelo enunciador do discurso jornalístico [2] cria um efeito de sentido acusatório que leva o co-enunciador a rever a imagem da instituição GM enquanto aquela que pode dizer o que diz:

[Título] Hipocrisia sobre rodas: GM vende carro 'contra corrupção', mas é condenada por fraudes.

Por meio da construção de uma cenografia digital, o discurso jornalístico [2] emparelha duas imagens. A cenografia digital opera uma montagem colocando lado a lado a imagem do novo carro da GM - com a palavra-chave "\#SEJAAMUDANÇA"11 - e a imagem de um carro incendiado do modelo Vectra. Esta última imagem fora postada preservando o caráter de "confiabilidade" da informação, ou seja, o carro incendiado na cenografia digital foi apresentado por meio de uma cenografia jornalística.

A cenografia jornalística permite ao co-enunciador receber o discurso como informação merecedora de crédito. O corpo iconotextual se apresenta reduzido e o texto foi organizado em parágrafos curtos. O co-enunciador recebe o discurso pela cenografia jornalística e pode, então, reorganizar a ordem dos discursos, avo-

11 O uso do símbolo [\#] conhecido como hashtag é utilizado para categorizar conteúdos publicados na internet, muitas vezes, os hashtags são transformados em hiperlinks. É nesse sentido, também, que fazemos referência à categoria da cenografia digital postulada por Maingueneau $(2015,2016)$. 
cando à memória os discursos da corrupção e os das manifestações anticorrupção na história recente do Brasil. Por isso, a cenografia construída evoca uma investigação.

Nesse quadro, o enunciador recorta a dimensão ético-moral do discurso da corrupção, pondo em xeque o regime de fala do discurso publicitário [1]. Com isso, visa a fazer corresponder o enunciador da publicidade à instância jurídica representada pela GM:

[\$4] [...] com o mesmo modelo Cruze que ela quer vender com o discurso 'politicamente correto', a empresa está sendo acusada de fraudar as medições antipoluição nos Estados Unidos.

Também,

[\$5] [...] com outros modelos, por conta de defeitos de fabricação, demora no recall e perda de valor dos veículos, a GM sofre processos bilionários [...]. E aqui mesmo no Brasil, arrasta-se há anos o caso judicial envolvendo a montadora com incêndios, num total de 32 acidentes e 24 vítimas fatais.

O co-enunciador, imerso na cenografia jornalístico-investigativa, recebe informações que desmoralizam, no campo da ética e da moral, a instância jurídica GM. Se bem entendido, esse movimento produz uma contradição para o enunciador do discurso publicitário [1]: não se pode falar de ética se não é ético. $O$ efeito de sentido acusatório cria uma tensão no diálogo, mas, em toda sua extensionalidade, produz-se, no debate anticorrupção, o mito 
do discurso teológico do ser puro, o Adão antes da queda. Afinal, a corrupção é o outro.

Da cenografia construída pelo discurso jornalístico [2] emerge um ethos de um leitor atento, crítico, aquele que revela as contradições do outro, suas hipocrisias, seu cinismo; um ethos como qual o co-enunciador pode aderir. Assim, o enunciador do discurso jornalístico [2] ocupa a função de leitor "crítico" da publicidade da GM e, ao mesmo tempo, de jornalista investigativo, revelando, no campo ético-moral, as contradições da enunciação publicitária:

[\$2] Ok, muito bem, embora misturar civismo e automóvel seja uma coisa pra lá de capciosa, coisa que a Fiat já fez com o tal "vem pra rua" com resultados duvidosíssimos.

A cenografia jornalístico-investigativa se legitima pelo progresso da enunciação que descredita o ato de civismo e de engajamento sociopolítico construído pela cenografia de protestos anticorrupção:

[\$3] Ocorre que a GM joga pedras, mas tem telhado de vidro.

Tendo em vista as condições sócio-históricas e culturais contemporâneas, em particular, no Brasil, o êxito da enunciabilidade do discurso publicitário [1] e do discurso jornalístico [2] é possível, mas agenciando cenas de fala validadas para basilar a construção das respectivas cenografias. No discurso publicitário [1], o jogo discursivo ocorre por meio do elã cívico que se instaurou, à época da companha da GM, no meio de inúmeros escândalos de 
empresários e agentes políticos. No discurso jornalístico [2], é a crítica do uso daquele elã para fins publicitários que se faz presente. Mas a estratégia, em ambos os discursos, é recorrer a cenas de fala validadas no campo da ética e da moral.

Não é preciso dizer que os enunciadores ocupam posições distintas no campo midiático. O enunciador do discurso publicitário [1] enuncia, partindo de um espaço purificado de consumo. Por sua vez, o enunciador do discurso jornalístico [2] enuncia do espaço social do embate, fora do exercício do consumo, particularmente, no lugar do jornalismo em uma imprensa livre. O primeiro recupera cenas de fala validadas recentes do Brasil, instaladas na memória do co-enunciador: manifestações cívicas, luta por direitos sociais, apartidarismo político. O segundo recupera cenas de fala do espaço social das inter-relações humanas, cenas, muitas vezes, esquecidas nas relações institucionais: ser justo, ser ético, ser honesto.

Além disso, a fim gestar uma expectativa de mudança na sociedade brasileira, o enunciador do discurso publicitário [1] apresenta o discurso da corrupção por meio de uma cenografia de protesto anticorrupção, incluindo-se como elemento ativo: "Somos um povo [...] que tá mudando pra servir de exemplo". O enunciador do discurso jornalístico [2] contesta não o discurso de "mudança", mas a instância autoral que tenta legitimá-lo. É ela que ele acusa o ato corruptível, convertendo o enunciador em instância jurídica para, na dimensão ético-moral, desnudá-la.

O enunciador do discurso jornalístico [2], então, ocupa a função "leitor de publicidade" e evoca um leitor-modelo com qual se espera a filiação do co-enunciador, leitor do site jornalístico. Essa adesão, no entanto, ocorre na dimensão ético-moral do discurso da corrupção: 
[\$7] Que tal a GM, que consumiu dinheiro público para não falir na crise de 2008, começar a seguir os conselhos que ela própria dá, no comercial, quando sugere às pessoas a refletirem e buscarem uma mudança de atitude.

O co-enunciador, leitor desse atravessamento, é levado a crer que as pessoas, em posição de poder, estão submetidas a normas invisíveis das atividades corruptoras, por interesse próprio ou pelo grupo em que se situam. Ao passo que, sem a instância de poder, sobretudo financeiro, as pessoas poderiam, de maneira livre (ética) operar por meios legais.

\section{Considerações finais}

Neste artigo, buscamos examinar a dimensão ético-moral no discurso da corrupção, na formação discursiva temática "corrupção" construída para análise. Como vimos, uma das estratégias do enunciador-jornalista - leitor "indesejado" - foi tomar o discurso publicitário [1] por uma finalidade secundária, em seu estatuto mimotópico. Mas essa finalidade corresponde à cenografia construída pela enunciação publicitária, uma vez que a estratégia é interrogar o leitor-cidadão e, indiretamente, o leitor-consumidor. A novidade é que o enunciador-jornalístico personaliza a instituição GM e a toma como responsável pelo discurso. Sem dúvida, um gesto de leitura possível.

O discurso jornalístico [2], ao atravessar o discurso publicitário [1], coloca em jogo questões éticas e morais implicadas na campanha publicitária da GM, com o fim de acusar a montadora norte-americana de não seguir os "conselhos que ela própria dá, no comercial". Mas, em particular, como o fim de "despir" a instância 
discursiva - implicada na GM - e apresentá-la num espaço da ética e da moral em que ela poderia ser flagrada em sua própria contradição (você não tem moral para dizer isso!).

Essas cenografias em embate apenas podem ser materializadas pelo gesto de leitura proposto pela Configuração [1]. Não se trata de um gesto particular, mas possível. O importante foi fazer notar que, no espaço digital da internet, a produção da leitura tende a ocorrer por meio de cenografias em continuidade. Essa ideia nos remete a noção de cenografia digital, postulada por Maingueneau $(2015,2016)$. Como observamos na análise, "seguimos" o caminho trilhado pelo enunciador-leitor-jornalista, que materializou sua leitura no gênero de texto "reportagem". A cenografia digital construída no site noticioso nos forneceu seu componente arquitetural, com o qual podemos interagir com a cenografia digital construída pelo discurso publicitário. Em nossa opinião, o fio condutor que as une diz respeito à temática da corrupção, mas, em particular, a maneira pela qual essa temática é tratada pelos enunciadores.

$\mathrm{Na}$ enunciação publicitária, a temática é apreendida a partir das condições sócio-históricas e políticas do lançamento da campanha da GM, em 2017. Essas condições tinham recorrências desde pelo menos 2013 com as manifestações de rua de maio daquele ano. Depois, em 2014, como as eleições presidenciais, se estenderam até e além do processo de impeachment da presidente Dilma Rousseff, em 2016. Em outras palavras, a enunciação publicitária trata o tema da corrupção pela dimensão ético-moral, colocando em primeiro plano o nível institucional e, em segundo plano, o nível individual, neste último estimulando o exercício individual do consumo.

$\mathrm{Na}$ enunciação jornalística, a temática é apreendida em confronto com a enunciação publicitária. O movimento é intertextual 
e interdiscurso. Mas são as mesmas condições sócio-históricas e políticas que são mobilizadas para pôr em xeque a legitimidade na enunciação publicitária. A dimensão ético-moral, aqui, é retomada para iluminar o aspecto ético, ou melhor, a falta de ética. Por isso, o enunciador-leitor-jornalista parte do nível individual para o nível institucional, mas, neste último, implicando não as instituições políticas, mas a instituição GM. Em última instância, quer-se dizer que não basta idealizar a ética, é preciso ter ética e ser ético.

Para isso, uma cenografia-investigativa é construída no discurso jornalístico. O enunciador-jornalista:

- Fornece dados: “a empresa está sendo acusada de fraudar as medições antipoluição nos Estados Unidos fontes” ou “[...] num total de 32 acidentes e 24 vítimas fatais";

- $\quad$ Recorre a outras fontes: "A Agência Pública, na Carta Capital, publicou matérias com o relato dramático das mortes"; e

- Mobiliza antecedentes: "Com outros modelos, por conta de defeitos de fabricação, demora no recall e perda de valor dos veículos, a GM sofre processos bilionários".

- Tira suas próprias conclusões: “[...] embora misturar civismo e automóvel seja uma coisa pra lá de capciosa, coisa que a Fiat já fez com o tal 'vem pra rua' com resultados duvidosíssimo"; "Que tal a GM, que consumiu dinheiro público para não falir na crise de 2008, começar a seguir os conselhos que ela própria dá, no comercial $[\ldots] "$.

O co-enunciador-leitor do jornal on-line recebe o iconotexto, postado no site, por uma cenografia investigativa que não pode dispensar seu estatuto digital, já que, além dos elementos citados, também produz uma montagem na imagem "anexada" ao gênero 
de texto "reportagem". A montagem, assim, visa a materializar a "contradição", a "hipocrisia" e, por fim, a falta de ética da instância jurídica implicada na GM, mas dialogando com o enunciador da publicidade, em particular, aderindo à cenografia de protesto anticorrupção.

\section{Referências}

BAUMAN, Zygmunt. A modernidade líquida. Tradução Plínio Dentzien. Rio de Janeiro: Jorge Zahar, 2001. BOBBIO, Norberto; MATTEUCCI, Nicola; PASQUINO, Gianfranco. Dicionário de política. Tradução Carmen C, Varriale et al. Coord. Trad. João Ferreira; ver. Geral João Ferreira e Luis Guerreiro Pinto Cacasi. 13.ed. Brasília: Universidade de Brasília, 2009.

GIDDENS, Anthony. As consequências da modernidade. Tradução de Raul Fiker. São Paulo: UNESP, 1991.

MAINGUENEAU, Dominique. Novas tendências em Análise do Discurso. 3.ed. Tradução Freda Indursky. Campinas, SP: Pontes: Universidade Estadual de Campina, 1997.

. Discurso Literário. Tradução Adail Sobral. São Paulo: Contexto, 2006.

. Cenas da enunciação. Sírio Possenti e Maria Cecília Péres Souza-e-Silva (Orgs.). São Paulo, Parábola, 2008.

Ethos, cenografia, incorporação. In: Ruth Amossy (Org.). Imagens de si no discurso: a construção do ethos. São Paulo: Contexto, 2011.

. Análise de textos de comunicação. 6. ed. ampl. Tradução Cecília P. de Souza e Délcio Rocha. São Paulo: Cortez, 2013.

. Discurso e análise do discurso. Tradução Sírio Possenti. São Paulo: Parábola, 2015. 
. Retorno crítico sobre o ethos. In: BARONAS, Roberto Leiser; MESTI, Paula Camila; CARREON, Renata de Oliveira (Orgs.). Análise do Discurso: entorno da problemática do ethos, do político e de discursos constituintes. Campinas, SP: Pontes, 2016.

NASCIMENTO, Jarbas Vargas; FERREIRA, Anderson. Mimotopia e cenografia no discurso publicitário de empresas de seguro de vida e de assistência funerária. Calidoscópio, v. 14, p. 257-264, 2016.

ORLANDI, Eni Puccinelli. Texto e Discurso, Organon, v.9, n.23, 1995, p. 111-118. 